\title{
Local Wisdom on the Use of Minangkabau Proverbs Meaning Satire by the Minangkabau Community in Medan
}

\author{
Syamsul Bahri \\ State University of Medan
}

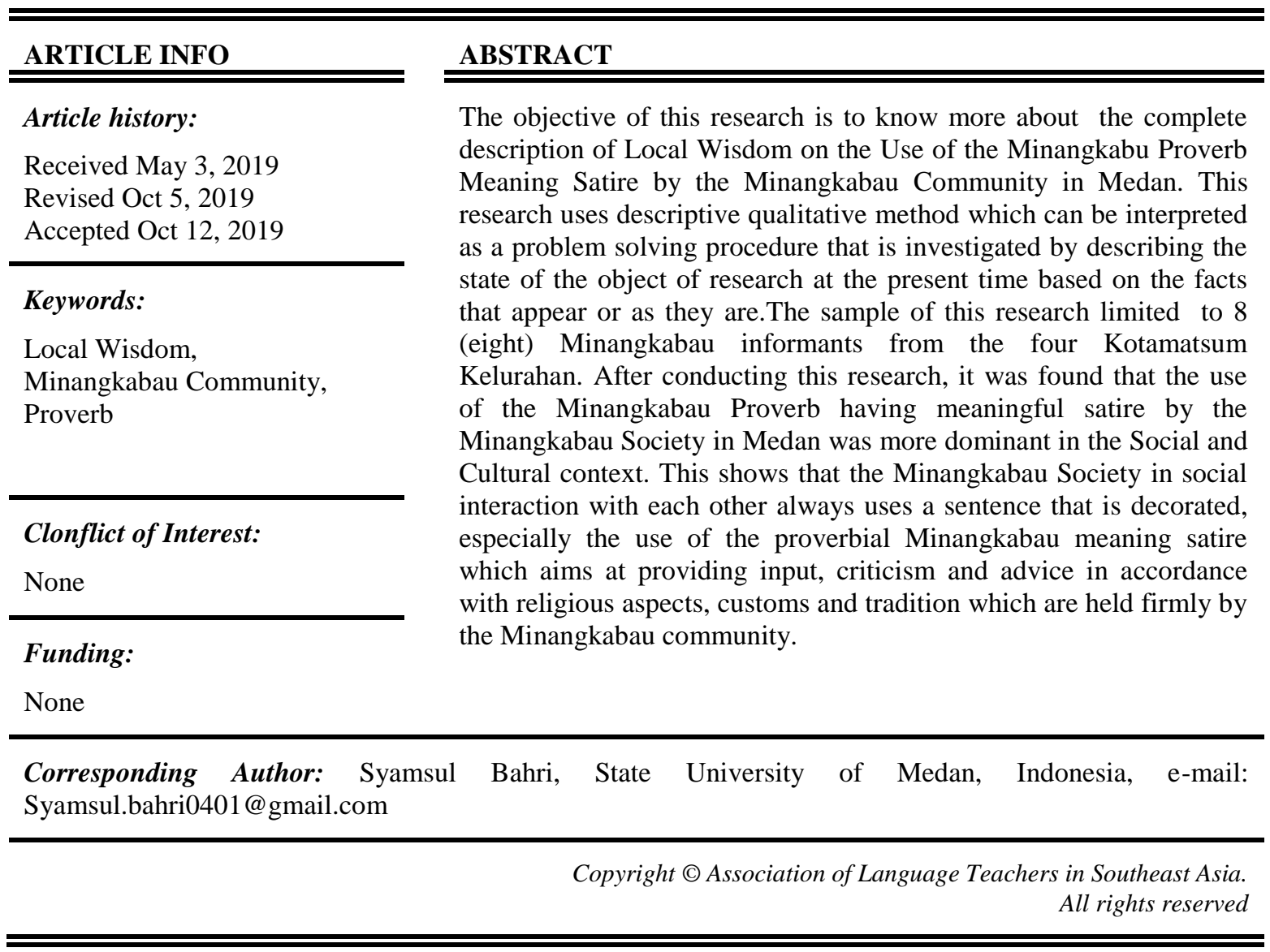

\section{Introduction}

Indonesia, which consists of various ethnic groups, certainly has a diversity of regional languages that enrich Indonesian. One of the regional languages is Minangkabau. The Minangkabau language has experienced a rapid spread to various regions in Indonesia. This is due to the strong attitude and tradition of migrating for the Minangkabau people from West Sumatera to various regions in Indonesia. Wander attitudes and patterns that are carried out in line with customs and tradition that continue to be used wherever located, especially the attitude of preservation of the Minangkabau language used by its speakers.

One of the areas encountered by many Minangkabau people who still use and preserve the Minangkabau language is Medan. As a migrant community in Medan in a family environment, in daily life, and at traditional community gatherings, the Minangkabau people continue to use and preserve the Minangkabau language. However, it is not uncommon to find that the Minangkabau people always use decorated language in the form of proverbs. The speech culture, which is decorated with the Minangkabau community in proverbial expressions always abstracts forms, human nature, and greatly enriches their knowledge in communicating and giving birth to figurative forms. Figurative language in speech can be said as a marker of Minangkabau people's identity in communication. It is also intended to beautify and refine the language conveyed even though it was with the intention of innuendo. The research of the Minangkabau proverb which means satire is a regional language research conducted with the intention as an effort and effort in the 
improvement, development, fostering and preservation of regional languages in order to enrich Indonesian as a national language. Previous studies conducted in an effort to improve, develop, foster and preserve the Minangkabau language such as, (1) The Use of Minangkabau Proverbs of Contrast Meanings by Minangkabau Society in Medan by Meisuri dan Syamsul Bahri, 2019. (2) Minangkabau Proverb: Stimulating High School Students' Critical Thinking and Spatial Thinking by Silvia Marni at all, 2019.(3) Satirical News Detection and Analysis using Attention Mechanism and Linguistic Features by Fan Yang and Arjun Mukherjee ,2017. (4) Television satire, democracy and the decay of public language: John Clarke's verbal caricature by Amanda Roe ,2006.(5) Notes on the Variety and Uses of Satire, Sarcasm and Irony in Social Research, with Some Observations on Vices and Follies in the Academy by Cate Watson, 2011. (6) Satire, social media and revolutionary cultural production in the Bahrain uprising: From Utopian fiction to political satire by Marc Owen Jones, 2017.

Researcher believes that there are still many other studies relating to Minangkabau proverbs and satire, starting from the development of previous studies, the research to be carried out is entitled: "Local Wisdom on the Use of Minangkabau Proverbs Meaning Satire by the Minangkabau Community in Medan". So far, it can be said that the same research has never been done, but although there is the problems to be examined in this study are: How is the complete description of Local Wisdom on the Use of Minangkabu Proverbs Meaning Satire by the Minangkabau Community in Medan?

\section{Review Literature}

\subsection{Local Wisdom}

Local wisdom is an aspect of knowledge, understanding, beliefs, or insight or ethics that guide human behavior of life in the community. Local wisdom is part of the culture of a society that cannot be separated from the language of the community itself. That is in line with what Sibarani states (2014:114) Local wisdom is local ideas and knowledge that is wise, full of wisdom, good value, virtuous owned, guided and implemented by members of the community. Local wisdom which is defined as the knowledge of local people who are wise, full of wisdom, good value and virtuous that are owned, guided and carried out by members of the community. Local wisdom itself used by the wider community to regulate the way of life of society wisely to preserve ancestors and culture. In Local wisdom, there is the maturity of the community at the local community level, which is reflected in attitudes and behaviors to bring about change for the better, as said by the Indonesian Ministry of Social Affairs and Social Affairs (2005:5-15).

\subsection{Satire}

According to Leboeuf (2007: 2) Satire is a very powerful artistic form used to critique and to point out the deficiencies in specific human behaviors. It can be interpreted that Satire (Satire) is a form that contains artistic value and strength in criticizing and showing the lack of deficiencies existing in human attitudes and behavior. Waridah (2014: 29-31) classifies Satire into five types namely:

\section{Irony}

The style of language to express an intention uses words that are different or contrary to that purpose,such as:

$>$ You are indeed a model student, in one week, only one day you arrive on time.

$>$ The contents of your report are so complete that we cannot grasp the contents of the problem

\section{Sarcasm}

Style of language that contains abusive insinuations,such as :

$>$ Shut up! It hurts my ears to hear your babble

$>$ I do not want to live in your house that looks more like a sheepfold

\section{Cynicism}

Allusions in the form of doubtful stories contain mock of sincerity,such as :

$>$ Already, stop persuading your ray because it only makes me more ill.

$>$ His speed in making decisions often confuses his people.

\section{Antifrasis}

Irony style with words or groups of words with opposite meanings,such as:

$>$ "Ha ... ha ... the skinny confused looking for clothes to cover his bulging belly."

$>$ "Look at the midget going to get the ball in the cupboard!"

\section{Inuedo}

Allusions that are understating the real facts,such as : 
$>$ He became the owner of the land in the area thanks to his shrewdness with the authorities.

$>$ The young man managed to occupy an important position thanks to the services of his father who sat on the board of commissioners.

\subsection{Proverbs}

Satire is different from proverb. According to Waridah (2012: 364) proverbs are sentences or groups of words which compose one specific purpose. The wording in the proverb is fixed because if it is changed, the wording can no longer be called a proverb, but rather as an ordinary sentence. Furthermore, Waridah (2012: 364-386) classifies Proverbs into three types namely proverbs, parables, and expressions.

\section{Maxim}

The saying is a proverb that contains advice or teachings. For example:

a. Children on the lap are released, Monkey in the jungle in breastfeeding

Others' affairs are resolved, while one's own affairs are ignored

b. Behind the machete even if sharpened it will be sharp too

if a fool wants to learn, He must be smart too

c. Silence in the city does not imitate, silence in the sea is not salty

People who are reluctant to study even though they have been staying for a long time.

\section{Parables}

Parables are proverbs that contain comparisons. These types of proverbs are characterized by the use of meaningful words comparing them such as, like. For example:

a. Like a virgin you are drunk

Someone who looks weak and tired,in fact, he is not sick

b. Like a starred moon

A woman who is beautiful and loved by her siblings; Very ideal

c. As big as on the slopes, high as the flat-head

Grow big or grow fast

\section{The phrase}

Phrases are special words or groups of words to express an intent. The composition of words in expressions is fixed and cannot be interleaved with other words. The meaning of an expression cannot be seen from every word element that forms it and will be easier to understand if it is related to the context of the sentence. As an example:

\section{a. Tiger Toothless}

Something that looks strong, but is actually not powerful and docile

\section{b. Dig your own grave}

Formulate yourself

c. Broken mayang

Wavy (about hair)

Proverbs are expressions that contain advice and teachings expressed through figurative language and are used to create certain effects that have their own beauty. In everyday life proverbs are used by all groups of children and adults and are used in both formal and informal environments. Proverbs are appropriate to use both in the educational environment or the general environment.

\subsection{Minangkabau Proverb}

Minangkabau is a rich region full of proverbs in its language. Proverbs are used among the society of Minangkabau,such as :

1. Talunjuak is better at Kalingking (a person whose mouth is sweet, in front of us is good but his heart is bad).

2. Tarandam-Randam not wet, wasted nothing

(an issue that is not firmly established and its implementation neglected).

3. Suckle, wobbly, tired and not happy

(people who do not like to be frank and there is no firmness in something).

\subsection{Minangkabau proverb which means satire in various contexts 1. Socio Cultural Context}


Example:

a) Talunjuak

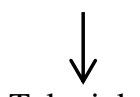

Telunjuk

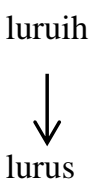

lurus

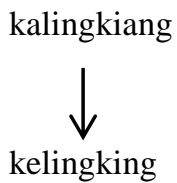

kelingking

(a person whose mouth is sweet, in front of us is good but his heart is bad)

\section{Politic Context}

Example:

a. Bulek jan

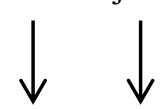<smiles>[134IH]</smiles><smiles>[AlH2][AlH2]</smiles>
basandiang

round don't angle thin

don`t side by side

(people who agree in a consensus because they are forced and become a conversation in the future).

\section{Economic Context}

Example:

a. Gapuak

mambuang

lamak
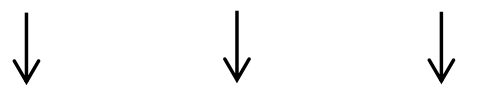

fat throw

tallow

(A clever person who harms others)

\section{Religion Context}

Example:

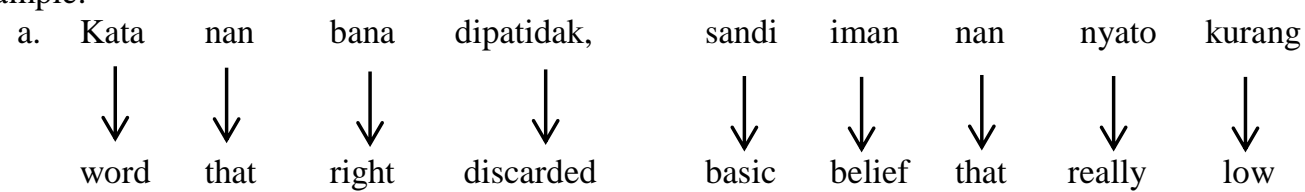

(Those who run away from the truth signify a very thin sense of their faith in God)

\section{Law Context}

Example:
a. Aluah
samo
dituruik, jajalan
samo
ditampuah<smiles>CCCC</smiles><smiles>CCCCC</smiles><smiles>C[AlH]</smiles><smiles>C=[V]</smiles><smiles>C1CCCCC1</smiles><smiles>CCCC</smiles>
flow same folowed
street
same
reached

(the rule of law must be carried out indiscriminately, must be fair)

\section{Method}

This research uses descriptive qualitative method which can be interpreted as a problem solving procedure that is investigated by describing the state of the object of research at the present time based on the facts that appear or as they are (Nawawi, 1998: 63). The research technique was carried out in a way that the researcher went directly to the informants who were used as a sample of this research and provided an instrument form that had to be filled in by informants about the meaningful sayings of allusions that occurred in five context conditions namely socio-cultural, political, legal, economic, and religion.

In the process of determining the population, the researchers determined that there are many Minangkabau communities in Medan, the researchers limited the population of this study to only the Minangkabau communities in the villages of Kotamatsum I, II, III, and IV. The informants from these four villages can represent the Minangkabau community in Medan because the majority of the population in these four areas are the Minangkabau Community. According to (Naim, 1979: 101) that $75 \%$ of the population of Kotamatsum are Minangkabau people who migrate to Medan. In this study, the sampling technique that was carried out is purposive sampling which means that the sample units contacted will be adjusted to certain criteria determined based on or leading to the achievement of research objectives (Nawawi, 1998: 157). 
Researchers took and limited the research sample to 8 (eight) Minang nomads from the four Kotamatsum Kelurahan. This means that from every Kelurahan Kotamatsum there are taken 2 (two) people as informants. The informants chosen were Minang migrants who had lived in West Sumatra for a long time from birth to adulthood and were aged 35 years and older, which meant that they had mastered the Minangkabau language. The informants were selected from families who were still strict in their area or often used the Minangkabau language in the family environment, regional families and at customary events. The age of the informants is also limited to Minang immigrants aged 35 years or more.

This research analyzed data in the form of the Minangkabau proverb which means satire pronounced by Minangkabau speakers in Medan. After the data are collected and grouped according to its context, identification, study and analysis of the Minangkabau proverb meaningful allusions are found in the five contexts, namely the socio-cultural, Political, Economic, Legal and Religious contexts.

\section{Result and Discussion}

\subsection{Result}

After conducting this research, it was found that the use of the Minangkabau Proverb meaningful satire by the Minangkabau Society in Medan was more dominant in the Social and Cultural context which reached $59.3 \%$, in the Economic and Religious context equally reaching $12.5 \%$, in the Legal context it reached $9.3 \%$ and the lowest occurred in the political context which only reached $6.2 \%$. This shows that the Minangkabau Society in social interaction with each other always uses a sentence that is decorated, especially the use of the proverbial Minangkabau meaning satire which aims to provide input, criticism and advice in accordance with religious teachings, customs and karma which is held firmly by the Minangkabau community. This satire is a decorative sentence used to insinuate and give subtle advice so that it can be acceptable to those involved in social communication interactions among fellow Minangkabau people and at the same time as social control among Minangkabau people in interacting with each other then in acting and speaking the Minangkabau Society to be more careful in accordance with the rules of customs and religion and manners that apply to the Minangkabau Society so as to create a conducive atmosphere, formed conditions that are safe, tram and in accordance with the rules, provisions and norms that exist in the Minangkabau Society.

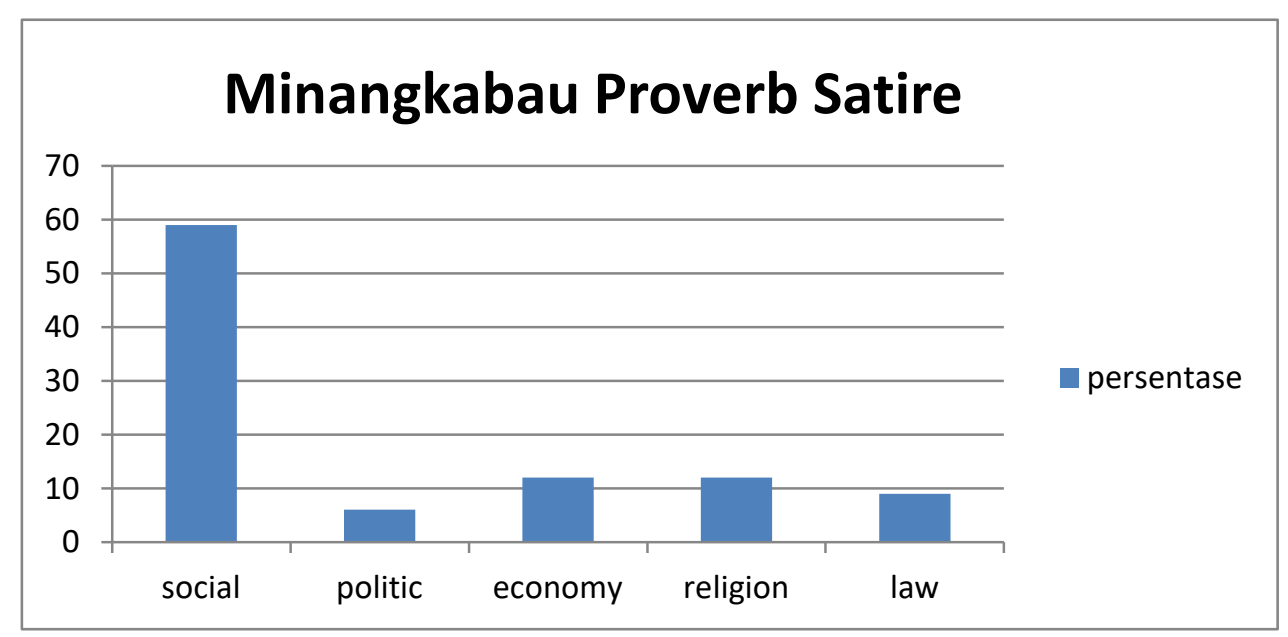

Figure 1. The Realization of Minangkabau Proverb Satire

\subsection{Discussion}

Minangkabau Proverbs which means satire in some contexts, those are:

\section{Socio-cultural Context}

a. Talunjuak<smiles>C=[V]</smiles>

index finger luruih<smiles>C=IC</smiles>

straightt

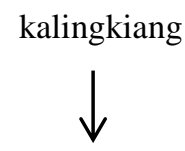

little finger

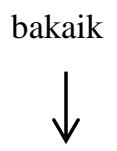

bend

(a person whose mouth is sweet, in front of us is good but his heart is bad)

This Minangkabau proverb has a satirical meaning for people with other characters in the mouth of the other in their hearts, insinuating those who often speak softly and sweetly but have bad intentions and intentions. 

b) Ayam
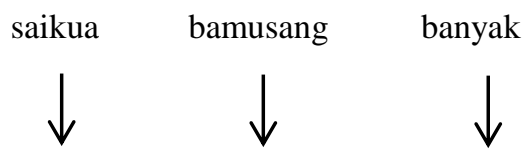
chicken
a
have a civet
many

(people who have many enemies)

This Minangkabau proverb has a satirical meaning for people who are not good at socializing and quarrelsome and have many enemies.

c) Bungo kambang

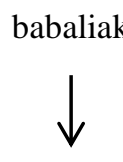

Flower bloom

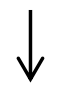

back

kuncuik

(People who are considered noble turn away)

This proverbial Minangkabau has a satirical meaning for people who are initially good, pious and like to do good deeds, changing their attitudes into people who deny the bad and bad temperament in society.

\section{Politic Context}

a. Dalam politik

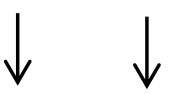

In politic

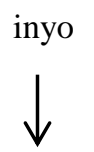

he

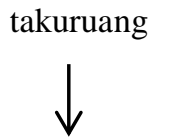

isolated

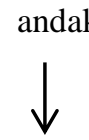

want

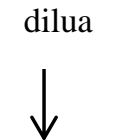

outside

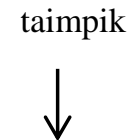

hit andak diateh

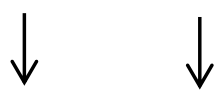

want on

(people who do not want to lose the debate and are difficult to manage, just want to win)

This Minangkabau proverb insinuates people who do not want to lose the debate, want to win themselves and are difficult to regulate with the existing system.

b. Bulek jan basaduik picak jan basandiang

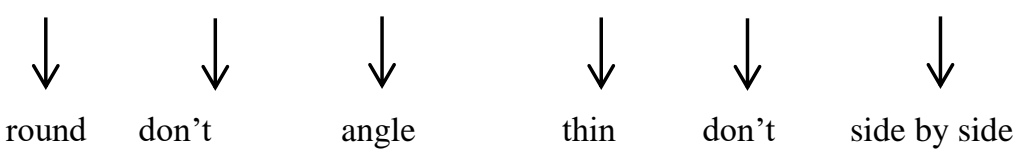

(people who agree in a consensus because they are forced and become a conversation in the future)

This Minangkabau proverb insinuates people who like to bring up and talk behind the forum something that he has agreed with the reason for being forced, people who do not have the sincerity of giving words of consensus and become a byword called in the future.

\section{Economic context}

a. Itiak baranan<smiles>C=[V]</smiles><smiles>C1CCCC1</smiles>

duck
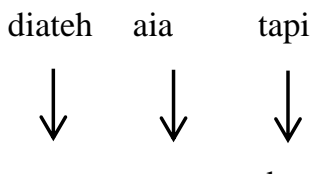

mati

kehausan

(A rich person has abundant wealth but cannot enjoy his wealth)

This Minangkabau proverb insinuates people who are in wealth and financial and wealth but can not enjoy wealth.

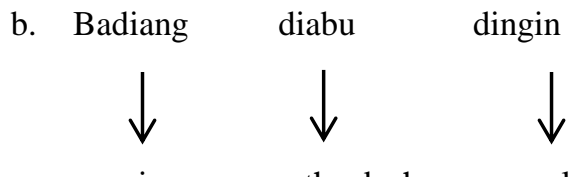

(people who ask for help from people who might not fulfill it)

This Minangkabau proverb insinuates those who ask for help from those who cannot and cannot fulfill it.

c. Gapuak

mambuang

lamak
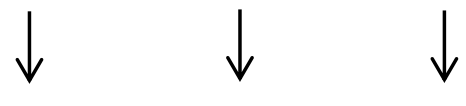

Fat

throw

tallow

(A clever person who harms others)

This Minangkabau proverb insinuates people who always act cleverly but often harm others. 


\section{Religion context}

Example:

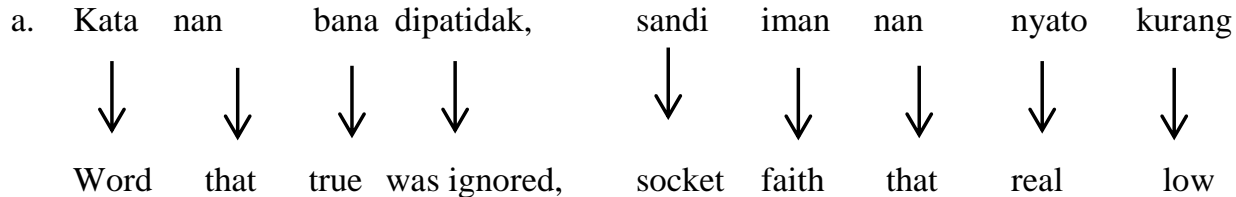

(Running away from the truth indicates a very thin sense of faith in God)

This Minangkabau proverb insinuates people like to do something outside the truth, like to do something that is not in accordance with religion.

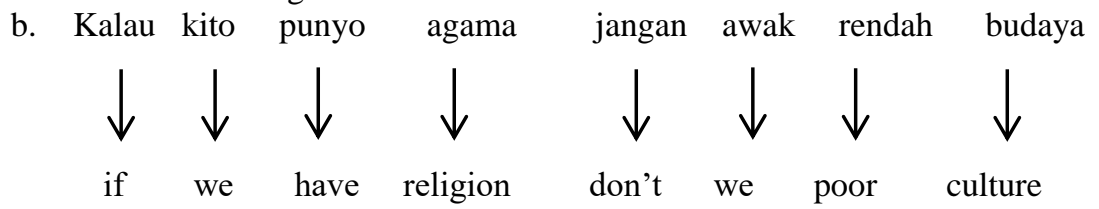

This Minangkabau saying insinuates people not to be poor in culture because we live with a religion that is a role model and guide in every life.

c. Dunia sudah kiamat tibo, jalan luruih labuah basimpang

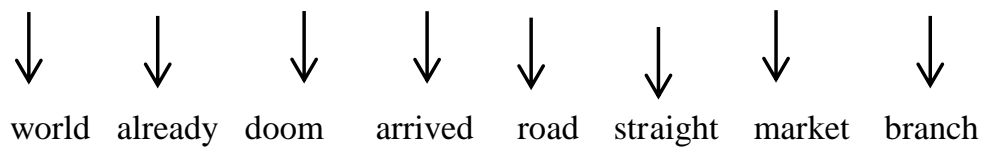

(After the Day of Judgment two roads must be taken; the road to surge and the road to hell)

This Minangkabau proverb satirizes as well as advises people who go through life on this earth to have two choices whether to follow the right path or not, this life will end in hell or heaven.

\section{Law context}

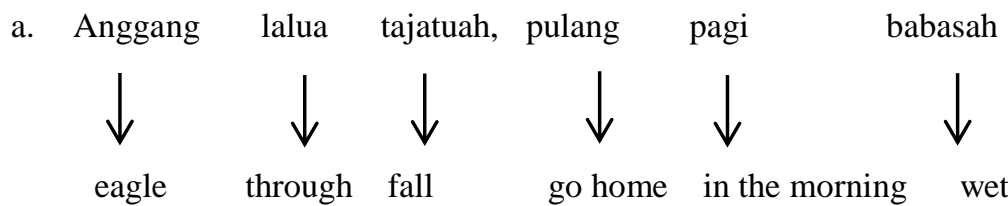

(Someone who can be accused for suspicious things)

This Minangkabau proverb insinuates people who do suspicious things and have the possibility to be accused by others.

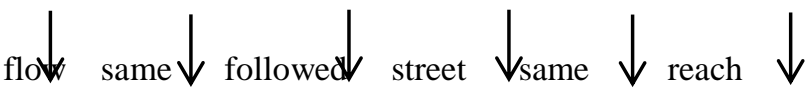

(The rule of law must be carried out indiscriminately and fairly)

This Minangkabau proverb insinuates people to be fair and behave the same towards the rule of law for all people.

c. Aluah hutang patuik dibaie, aluah hokum patuik dibangun

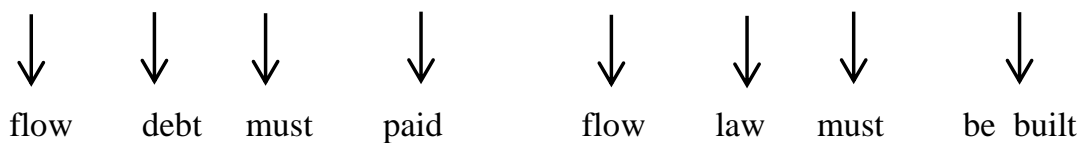

(penalties that can be carried out with a payment / fine)

This Minangkabau proverb insinuates those who carelessly with the law to continue to enforce the implementation of the law in accordance with applicable legal principles, penalties that can be carried out with a fine payment, and the implementation of applicable law.

\section{Conclusion}

The ornate sentences spoken by the Minangkabau community in the form of a proverb are often used to convey innuendos to someone. The proverb of the Minangkabau satire is spoken while giving warnings or advice to someone. In this research, it can be concluded that Minangkabau proverbs which means satire used by Minangkabau community could be in form of sentence that contains elements of advice and constructive criticism for people who listen to it. 
As an example in the sentence "awaktubatalunjuakluruihkalingkiangbakayiek", this element has an element of criticism or sarcasm to people who like to have a sweet mouth but are liars and do something contrary to what is said.

After doing this research, it can be said that the Minangkabau proverb which means satire on the Minangkabau community in Medan occurs in several contexts of situation namely socio-cultural, economic context, legal context, political context, and religious context. This is a picture or representation of the customs, culture, attitudes and ideology of the Minangkabau people's life order. The habit of speaking and decorating by using a saying that contains satire, it aims to provide criticism, advice and direction about, the right manners and rules in accordance with the religion and customs of the Minangkabau Society. The proverbial Minangkabau meaning satire also has a function as a social control of the Minangkabau community so that in behaving and behaving to always be in the right corridor. Can be given an example in the adage "High basambal crew" which has the meaning of satire against people who are always arrogant style in society, behave and behave like a rich person, but in fact he has the opposite life. Minangkabau proverb means this insinuation implies having an innocent attitude functions as a social control of the Minagkabau Society that in acting should be in accordance with our true existence and must avoid being arrogant in the community.

The Minangkabau proverb means these allusions occur in 5 (five) contexts of the situation, namely in the context of socio-cultural, economic, legal, political and religious. From the results of research conducted that the meaningful proverbial percentage of innuendo obtained in the socio-cultural context is greater that is $43.75 \%$, then in the economic context the results are as much as $21.87 \%$, then in the religious context the results are as much as $15.62 \%$, while in the political and legal context has the same percentage of results, which is $9.37 \%$.

This also confirms that in social interaction between individuals within the community in Minangkabau custom is always dressed up with a proverb which means satire. Communicate with each other in forming a social interaction that cannot be separated from traditions, customs, and culture. The proverbial Minangkabau proverb means satire that gives a distinctive character to the Minangkabau community who likes to speak in kias language that reflects attitudes, customs, culture and also as social control of the Minangkabau Society.

\section{References}

Alexander, L. G. (1963). Poetry and Prose Appreciation for Overseas Students. Essex: Longman.

Bahri, S. (2001). Inteferensi Bahasa Minangkabau dalam Bahasa Indonesia pada Masyarakat Minang Perantau di Medan. Medan: Universitas Sumatera Utara.

Jones, M.O. (2017). Satire, social media and revolutionary cultural production in the Bahrain uprising: From utopian fiction to political satire. United Kingdom: Sage.

Meisuri et al. (2019). The Use of Minangkabau Proverbs of Contrast Meanings by Minangkabau Society in Medan. Belgium: Budapest Institute.

Marni, S. et al. (2020). Minangkabau Proverb: Stimulating High School Students' Critical Thinking and Spatial Thinking. Jakarta: Scitepress.

Nafis, A. (1996). Peribahasa Minangkabau. Jakarta: PT. Intermasa.

Penghulu, D. (1984). 1000 Pepatah-Petitih, Mamang, Bidal, Pantundan Gurindam : PT. RemajaRosdakarya.

Roe, A. (2006). Television sat ire, democra cy and the decay of public language: John Clarke's verbal caricat ure.

Saleh, A.A. (1999). "Ungkapan Minangkabau”. Laporan Penelitian oleh Lembaga Kerapatan Adat Alam Minangkabau Padang.

Sibarani, R. (2014). Kearifan Lokal Hakikat, Peran, dan Metode Tradisi Lisan. Jakarta: Asosiasi Tradisi Lisan (ATL)

Waridah, E. (2013). EYD Ejaan yang Disempurnakan \& Seputar Kebahasaan-Indonesia. Jakarta: PT. Kawah Media.

Watson, C. (2011). Notes On The Variety And Uses Of Satire, Sarcasm And Irony In Social Research, With Some Observations On Vices And Follies In The Academy. United Kingdom: Power And Education.

Yang, F. et al. (2017). Satirical News Detection and Analysis using Attention Mechanism and Linguistic Features. Copenhagen, Denmark: Association for Computational Linguistics. 